\title{
IMPACT OF DIVIDEND PAYOUT ON THE FIRM VALUE: A STUDY OF FIRMS LISTED ON NATIONAL STOCK EXCHANGE
}

\author{
Dr.Chinnaiah.P.M., \\ Assistant Professor, DOS\&R in Management, KSOU, Mysuru-06.
}

Article DOI: $\underline{\text { https://doi.org/10.36713/epra5211 }}$

\begin{abstract}
-
Maximization of firm value or shareholders wealth maximization is the prime objective of a firm. As the dividend payout decision is one of the important decisions, its impact on the firm value has been widely studied and researched topic in the area of corporate finance. In the present study the impact of dividend payout on the value of the firm has been examined on the sample of Nifty-100 index firms. Along with the Dividend Payout(DPR), Current year's profit(CPR), Size(SIZE), Leverage(LEV), Growth Opportunities(GWOP), Market risk(Beta), PriceEarnings(PE) ratio and Age(AGE) have been considered in the model as independent variables. The result shows that, dividend payout positively related but not significantly influence on the value of the firm. Whereas, The Current year's profit (CPR), Size (SIZE), Growth Opportunities (GWOP) and Price-Earnings (PE) are the variables significantly influence on the value of the firm.
\end{abstract}

KEYWORDS: Dividend payout, value of the firm, shareholders, National Stock Exchange, market risk.

\section{INTRODUCTION}

Shareholder wealth maximization or firm value creation is the prime objective of finance a manager. The manager of a firm has to ensure that, his business decisions shall result in the firm value maximization. As the dividend decision is one of the important areas in the corporate finance. Hence, the impact of dividend policies on the value of the firms is widely researched topic, but still it is unsettled puzzle. In their seminal paper on dividend payout and value of the firm Miller and Modigliani(1961), argued that, dividend payout does not have any impact on the value of the firm. Whereas, Gordon, (1959); and Walter, (1963) had argued that, dividend payout influence on the value of the firm. After these works on the dividend payout, there are large number of studies have been conducted on different aspects of dividend payout (Darling, 1957; Lintner, 1956; Omran and Pointon, 2004; Pandey and Bhat, 2007).

The shareholders wealth maximization results in attraction of more funds to capital markets. Such attraction results in channelization of funds to the capital market, which leads to the economic growth of the country as a whole. Hence, as the dividend payout is one of the major decisions of finance a manager, the examination of impact of dividend payouts on the value of the firm in the Indian context is definitely an addition to existing knowledge of dividend policies.

The present study has been organized as follows: section one deals with introduction, section two focused on the review of literature, section three state the research question and objective of the study, section four presents the detailed research methodology, section five results and their discussion has been carried out and section six presented the conclusion. 


\section{REVIEW OF LITERATURE}

Gordon, (1959) in the research proved that' the value of the firm get impacted by the dividend decisions of a firm'. After this paper, Miller and Modigliani, (1961) in their seminal work on the dividend and value of the firm argued that, value of the firm is independent of its dividend payout'. Later, Walter, (1963) in the research argued that, ' the dividend policies of a firm influence on the value of the firm'. These three papers stand majors works on dividend policies till today.

Morovvati Siboni and Pourali, (2015) in their study on the impact of investment opportunities and dividend policy on the firm value, it is found that, both 'investment opportunities and the dividend policies have positive impact on the firm value' of firms listed in Tehran Stock Exchange.

Anton, (2016) in the study on the impact of dividend policy on the value of the firms of Romanian firms is found that, 'dividend positively and significantly influence on the value of the firm'.

Sinaga, (2016) conducted a study on the effect of the capital structure, firm growth and dividend policy on the profitability and firm value of the oil palm plantation companies in Indonesia. It is found that, the dividend policy positively and significantly influences on the profitability but positively and not significantly influence the firm value.

Rehman, (2016) conducted the study to examine the impact of capital structure and dividend policies on the value of a firm, on the sample of firm listed on Karachi Stock Exchange. In the study, it is found that, 'both capital structure and dividend policy variables significantly influence on the value of the firm'.

Lumapow and Tumiwa, (2017) on the sample of manufacturing companies those are listed on Indonesia Stock Exchange for the period of 2012-2016. It is found that, 'dividend payout ratio does not significantly influence on the value of the firm'.

Xiong, (2016) in his study on institutional investors, dividend policies and value of the firm found that, "the dividend payout leads to increase in the firm value 'in China.

Sudiani and Wiksuana, (2018) have conducted a study to examine the impact of leverage, investment opportunity, dividend policy and profitability; the results of the study shows that, 'dividend policies significantly influence on the value of the firm'.

Sondakh, (2019) has conducted a study to examine Dividend Policy, Liquidity, Profitability and Firm size on Firm Value in Financial Service Sector Industries Listed in Indonesia Stock Exchange-2018 Period. The study reveals that, 'Dividend policy negatively influence on the value of the firm.

Triani and Tarmidi, (2019) in their study on the impact of investment decision and dividend decisions; it is found that, 'value of the firm is influenced by the dividend payout of the sample firms listed on Indonesia Stock Exchange from 2013 to 2016'.

Odum et al., (2019) conducted their study on the impact of dividend payout on the firm value of firms listed on Nigerian Stock exchange. The study exhibits that, 'dividend decision does not impact on the value of the firm'.

As it is found in the above researches, the results are mixed, in some researches the value of the firm influenced by the dividend payout and in some other researches the value of the firm is not influenced by the dividend payout. In the present study, in addition to dividend payout, other important variables those influence on the value of the firm has been included in the model, they are: Current years Profitability (CPR), Size (SIZE), Leverage (LEV), Growth opportunities (GWOP, Market Risk (BETA), Market Risk (BETA), Price -Earnings Ratio (PE), Age (AGE)

\section{STATEMENT OF THE PROBLEM AND OBJECTIVES OF THE STUDY}

Though there are large numbers of studies have been conducted on the impact of dividend payout on the value of a firm. But, they vary in terms of geographical distribution and industry to industry, in some studies the dividend significantly influences on the value of a firm and in some other it does not impact. Upon the careful review of literature on the impact of dividend payout on the value of the firm. It is found that, there are scant studies those examined the impact of dividend payout on the firm value of Indian firms, specifically the Nifty-100 firms. Hence, it is recognized that, 'what is impact of dividend payout on the value of the firm?' is the question. Specifically the study has the following objective: 'To examine the impact of the dividend payout of the Nifty-100 firms'.

\section{Hypotheses:}

H0: Select determinants do not significantly influence on the value of the firms of Nifty-100 Index

H1: Select determinants significantly influence on the value of the firms of Nifty-100 Index 


\subsection{Data and Source}

\section{RESEARCH METHODOLOGY}

The study relied upon the secondary data. The data for the study has been obtained from Capitaline database, which one of the widely used data base for academic and corporate researches in India; the validity of the data has been cross checked with the randomly selected firms' annual reports and it is found no differences in the data. Other data has been obtained from National Stock Exchange website, and other published sources such as books, magazines, journals etc.,

\subsection{Sample and Sample Size}

The study is conducted on the NSE's Nifty-100 firms. In the present study all the non-financial firms which are being consistently part of NSE's Nifty-100 index from March 2010 to March 2019 are select for the study. After, screening by the above criteria, the final sample reached 39 non-financial firms. The index Nifty- 100 is represented by top 100 diversified stocks based on their market capitalization. The Nity-100 Index represents about $76.8 \%$ of the free float market capitalization of the stocks listed on NSE as on March 29, 2019(NSE indices.com).

\subsection{Tools and Techniques for the data analyses}

To analyze the data MS excel and Stata-13 version has been used. The ratios and percentages of different variables have been calculated as per theoretical explanations. To examine the fundamental characteristics of the data, descriptive statistics have been employed. Further, it is ensured that, the data has to be satisfied with the basic assumptions of models.

\subsection{Normality Tests}

The Normality tests are conducted to examine whether the data is properly modelled by a normal distribution or not. In the study Jarque-Bera test has been conducted. This test measures the difference of the skewness and kurtosis of the series with those from the normal distribution.

The statistic is computed as:

$$
\text { Jarque-Bera }=\frac{N}{6}\left(S^{2}+\frac{(K-3)^{2}}{4}\right)
$$

Where S means Skewness, and K- mean Kurtosis.

\subsection{Panel data analysis}

In the study there are 39 firms whose data has been obtained from March 2010 to March 2019. Hence, the data has both cross section and time series components. Thus, it is appropriate to use panel data analysis that considers cross-section and time effects.

\subsection{Fixed effect model vs Random effect model}

The applicability of the models depend on whether the cross section error components are correlated with the independent variables(Haldar et al., 2010). If they are correlated with the independent variables the Random effect model will be inappropriate to use. To test whether cross section error components are correlated with the explanatory variables we conducted Hausman test of cross-section random effects. If they are correlated, we use the fixed effect model.

The transformed data panel unit root, the random effect and fixed effect models (within) have been conducted, then Hausman Test is conducted, to decide which model is more appropriate. This shows the significant correlation of cross section error components with the explanatory variables.

Thus, to conduct fixed effect model. Finally, we have conducted two -way fixed effect model.

Our model is as follows:

$$
y i t=\alpha_{i}+\lambda_{t}+\beta_{1} x_{1 i t}+\ldots \ldots . .+\beta \mathrm{kx}_{\text {kit }}+\text { uit },
$$

Where:

$>\alpha_{i-t}$ he individual specific intercept

$>\lambda_{t}$-the time specific intercept

$>$ uit- $\mathrm{N}\left(0, \sigma_{\mathrm{u}}^{2}\right)$

To test the fixed effect model, random effect model and Hausman Test we used STAT-13. 


\subsection{Variables and their measurement}

Table-1: Variables

\begin{tabular}{|c|c|c|c|}
\hline $\begin{array}{c}\text { Sl } \\
\text { No }\end{array}$ & Variable & Measurement & $\begin{array}{c}\text { Theoretical } \\
\text { predicted } \\
\text { relation }\end{array}$ \\
\hline 1 & Value of the firm (TQ) & \multicolumn{2}{|c|}{$\begin{array}{l}\text { (Market value of equity + book value of debt)/Book value of total } \\
\text { assets(Sarkar, 2010) }\end{array}$} \\
\hline 2 & Dividend payout(DPR) & Total Cash Dividends Paid/ Total paid up share capital. & $\begin{array}{c}\text { Positive/Ne } \\
\text { gative }\end{array}$ \\
\hline 3 & $\begin{array}{l}\text { Current years } \\
\text { Profitability(CPR) }\end{array}$ & Net Profit/Net worth(Ghosh, 2008) & Positive \\
\hline 4 & Size(SIZE) & Natural log of total assets & Positive \\
\hline 5 & Leverage(LEV) & Long-term debt/Total assets & Negative \\
\hline 6 & $\begin{array}{l}\text { Growth } \\
\text { opportunities(GWOP) }\end{array}$ & Market value of equity/ book value of equity & Positive \\
\hline 7 & Market Risk(BETA) & Equity Beta & Negative \\
\hline 8 & Price -Earnings Ratio(PE) & Market Price per share/Earnings per share. & Positive \\
\hline 9 & Age(AGE) & $\begin{array}{c}\text { Natural logarithm of number of years from its } \\
\text { incorporation }\end{array}$ & Positive \\
\hline
\end{tabular}

\section{RESULTS AND DISCUSSION}

Table-2: Descriptive statistics

\begin{tabular}{|c|c|c|c|c|c|c|c|}
\hline Variable & Obs & Mean & Std.Dev. & Min & Max & Skewness & Kurtosis \\
\hline TQ & 390 & 5.94 & 8.91 & 0.40 & 67.97 & 3.77 & 20.05 \\
\hline DPR & 390 & 4.26 & 10.61 & 0.000 & 132.94 & 6.65 & 66.15 \\
\hline CPR & 390 & 6211.70 & 7931.64 & -5017.32 & 45721.0 & 2.44 & 9.43 \\
\hline SIZE & 390 & 9.87 & 1.30 & 5.80 & 13.25 & -0.09 & 2.95 \\
\hline LEV & 390 & 0.17 & 0.20 & 0.00 & 0.72 & 1.03 & 2.91 \\
\hline GWOP & 390 & 5.67 & 7.22 & 0.24 & 50.76 & 3.22 & 15.33 \\
\hline BETA & 390 & 0.86 & 0.35 & 0.17 & 1.74 & 0.47 & 2.51 \\
\hline PE & 388 & 35.24 & 110.45 & 0.00 & 1994.50 & 14.99 & 258.56 \\
\hline AGE & 390 & 45.42 & 25.76 & 3.00 & 112.00 & 0.66 & 2.47 \\
\hline
\end{tabular}

In the above table- 2 the results of descriptive statistics of all the variables has been presented. The mean firm value (TQ) is 5.94, which vary from 0.40 to maximum of 67.97 , indicating the firms in the sample are able to create higher firm value. The mean dividend payout ratio (DPR) is 4.26, indicating the firms in the sample have been paying relatively higher dividend. The current year's profit (CPR) is Rs.6211.70crores. This clearly shows the firms have higher average profits. The mean size (SIZE) of the firms is 9.87 that vary from 5.80 to 13.25; this indicates the Nifty -100 firms are larger in size. The mean leverage (LEV) of the Nifty-100 firms is 0.17 with a standard deviation of 0.20 ; it indicates the firms have moderate level of leverage. The growth opportunities (GWOP) is 5.67 this reveals the firms in the sample have higher growth opportunities. The Market risk (Beta) of the firms is 0.86, this reveals, the firms in the sample have lesser risk. Further, table-2 also reveals that, the mean Price-Earnings ratio (PE) is 35.24, this depicts, the market is paying 35.24 times of the earnings for the firm's share, which indicates the market has higher confidence on the Nifty-100 firms and they have higher growth expectation on these firms. The mean age (AGE) of the firms in the sample is 45.42 years of age. This indicates the firms in the sample have been persisting in the market over the longer period of time. 
Table-3: Summary of Results of Fixed-effects (within) regression

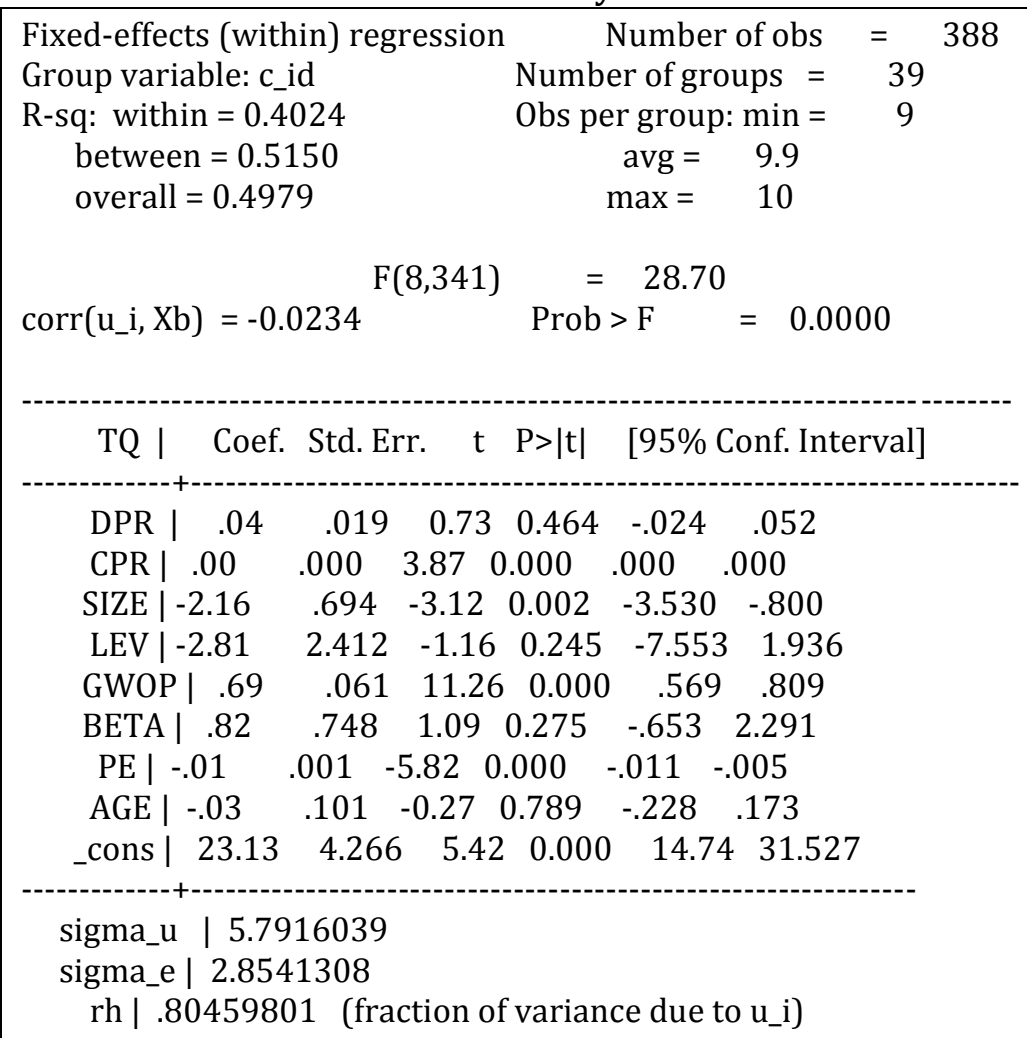

F test that all $\mathrm{u}_{\mathrm{i}} \mathrm{i}=0: \quad \mathrm{F}(38,341)=30.45 \quad$ Prob $>\mathrm{F}=0.0000$

In the above table- 3 presented the results of fixed effect model. It reveals, the F-value of 28.70 and the pvalue is 0.00 thus, the null hypothesis on' the select determinants do not have impact on the firm value' is rejected. This indicates, the select variables have significant impact on the firm value. It is interesting to note here, the dividend payout does not have significant impact on the value of the firms of Nifty -100 index. Further, the table-3 also reveals that, the current year's profit (CPR), size of the firm (SIZE), Growth opportunities (GWOP) and Price Earnings ratio (PE) have significant influence on the firm value. The positive and significant value of current year's profit (CPR) indicates, as the current year's profit increase the firm value also increases. The negative and significant relationship between the size (SIZE) and value of the firm may be due to the fact that, smaller size firms in the sample could be able generating higher firm value. The positive and significant relationship between the growth opportunities (GWOP) and value of the firm indicates, the firms those have higher growth opportunities have higher firm value. The negative relationship between the PE ratio and value of the firm indicates, higher the PE ratio lesser is the firm value, which is in contrast to the theoretical expectation.

\section{CONCLUSION}

Dividend payout and firm value is one of the important topics in the area of corporate finance that has been widely debated and researched area. Though there are large number of studies have been conducted on the dividend payout and its impact on the value of a firm, a study on Nifty-100 firms would be more appropriate study on the Indian context to generalize due to the fact that, the Nifty-100 index is higher diversified and covers more than 70 percent of free float market capitalization of firms listed on the NSE.

Thus, based on the literature, along with Dividend Payout Ratio (DPR) seven other variables have been incorporated in the model. The results of the study indicates, though the dividend payout ratio has positive coefficient but, it is not significant. The current year's profit (CPR), size of the firm (SIZE), growth opportunities (GWOP) and Price-earning (PE) ratios significantly influence on the value of the firm. Therefore, based on the 
findings of the study, it is concluded that, the dividend payout does not have significant impact on the value of the firms of Nifty-100 index firms.

\section{REFERENCE}

1. Anton, S.G., 2016. The impact of dividend policy on firm value. A panel data analysis of romanian listed firms. J. Public Adm. Finance Law 107-112.

2. Darling, P.G., 1957. The influence of expectations and liquidity on dividend policy. J. Polit. Econ. 65, 209-224.

3. Ghosh, S., 2008. Do leverage, dividend policy and profitability influence future value of firm? Evidence from India. Evid. India July 112008.

4. Gordon, M.J., 1959. Dividends, earnings, and stock prices. Rev. Econ. Stat. 99-105.

5. Haldar, A., Rao, S.N., Tayde, M., 2010. Ownership structure and firm performance: Evidence from India. Huntsville Tex. USA 96.

6. Lintner, J., 1956. Distribution of incomes of corporations among dividends, retained earnings, and taxes. Am. Econ. Rev. 46, 97-113.

7. Lumapow, L.S., Tumiwa, R.A.F., 2017. The effect of dividend policy, firm size, and productivity to the firm value. Res. J. Finance Account. 8, 20-24.

8. Miller, M.H., Modigliani, F., 1961. Dividend policy, growth, and the valuation of shares. J. Bus. 34, 411-433.

9. Morovvati Siboni, Z., Pourali, M.R., 2015. The Relationship between Investment Opportunity, Dividend Policy and Firm Value in Companies Listed in TSE: Evidence from IRAN. Eur. Online J. Nat. Soc. Sci. Proc. 4, pp-263.

10. Odum, A.N., Odum, C.G., Omeziri, R.I., Egbunike, C.F., 2019. Impact of dividend payout ratio on the value of firm: A study of companies listed on the Nigerian Stock Exchange. Indones. J. Contemp. Manag. Res. 1, 25-34.

11. Omran, M., Pointon, J., 2004. Dividend policy, trading characteristics and share prices: empirical evidence from Egyptian firms. Int. J. Theor. Appl. Finance 7, 121-133.

12. Pandey, I.M., Bhat, R., 2007. Dividend behaviour of Indian companies under monetary policy restrictions. Manag. Finance.

13. Rehman, O.U., 2016. Impact of capital structure and dividend policy on firm value. J. Poverty Invest. Dev. $21,40-57$.

14. Sarkar, J., 2010. Ownership and corporate governance in Indian firms. Corp. Gov. Emerg. Scenar. Natl. Stock Exch. India Ltd 217-267.

15. Sinaga, A.P.D.S.J., 2016. The effect of capital structure, firm growth and dividend policy on profitability and firm value of the oil palm plantation companies in Indonesia. Eur. J. Bus. Manag. Www Iiste Org ISSN 2222-1905.

16. Sondakh, R., 2019. The Effect of Dividend Policy, Liquidity, Profitability and Firm Size on Firm Value in Financial Service Sector Industries Listed in Indonesia Stock Exchange 2015-2018 Period. Accountability 8, 91-101.

17. Sudiani, N.K.A., Wiksuana, I.G., 2018. Capital structure, investment opportunity set, dividend policy and profitability as a firm value determinants. Russ. J. Agric. Socio-Econ. Sci. 81.

18. Triani, N., Tarmidi, D., 2019. Firm Value: Impact of Investment Decisions, Funding Decisions and Dividend Policies. Int. J. Acad. Res. Account. Finance Manag. Sci. 9, 158-163.

19. Walter, J.E., 1963. Dividend policy: its influence on the value of the enterprise. J. Finance 18, 280-291.

20. Xiong, J., 2016. Institutional Investors, Dividend Policy and Firm Value-Evidence from China. Open J. Soc. Sci. 4, $120-126$. 